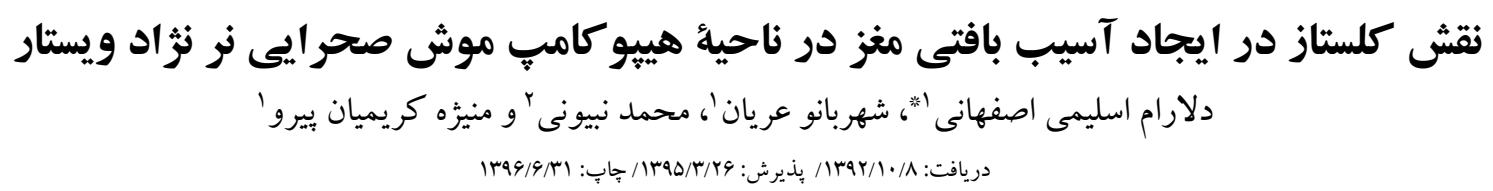

$$
\text { "اكروه علومجانورى، دانشكدة علومزيستى، دانشگاه خوارزمى، تهران، ايران }
$$

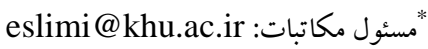

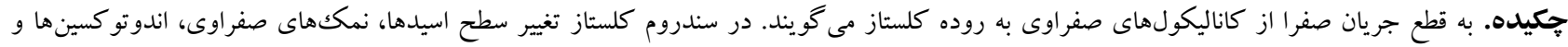

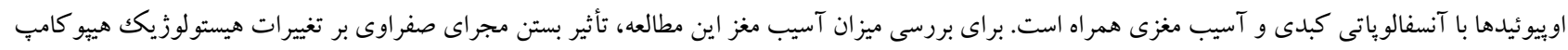

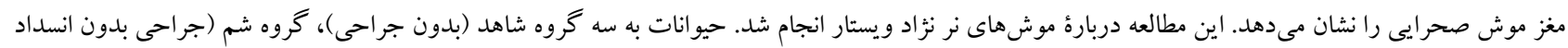

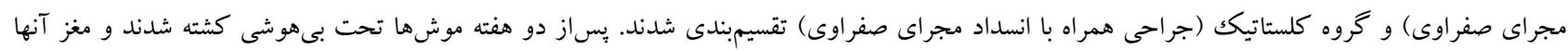

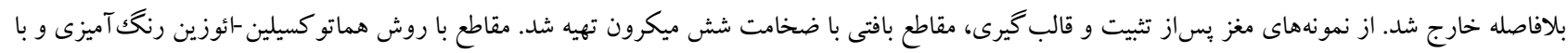

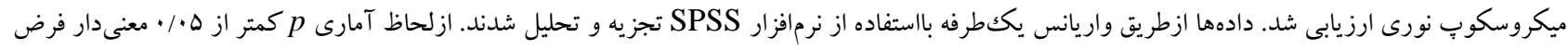

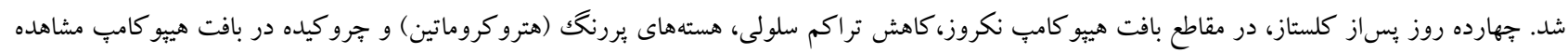

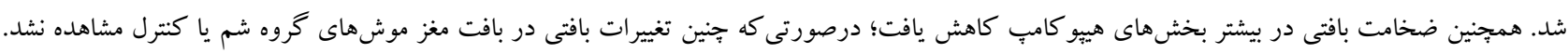

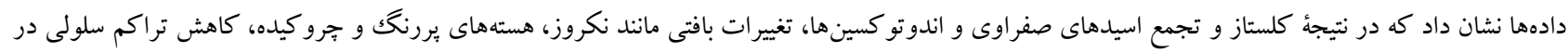

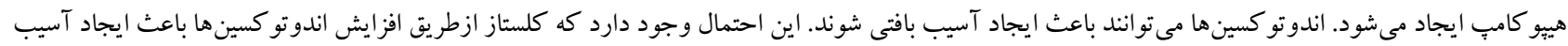

$$
\begin{aligned}
& \text { بافتى شده باشد. } \\
& \text { وازههاى كليدى. صفرا، اندوتو كسين، آنسفالوياتى كبدى، نكروز }
\end{aligned}
$$

\title{
The role of cholestasis in brain hippocampus trauma in male Wistar rat
}

\section{Delaram Eslimi Esfahani ${ }^{1 *}$, Shahrbanoo Oryan ${ }^{1}$, Mohammad Nabiuni ${ }^{2}$ \& Manijeh Karimian Peiro ${ }^{1}$ Received 28.12.2013/ Accepted 15.06.2016/ Published 22.09.2017}

${ }^{1}$ Department of Animal Biology, Faculty of Biological Sciences, Kharazmi University, Tehran, Iran ${ }^{2}$ Department of Cell and Molecular Sciences, Faculty of Biological Sciences, Kharazmi University, Tehran, Iran *Correspondent author: eslimi@khu.ac.ir

\begin{abstract}
In cholestasis syndrome, the change of bile acids, salts, endotoxins and opioidsis is accompanied with hepaticencephalopathy and brain trauma; therefore, in this study, the histopathological changes of hippocampus after bile duct ligation were investigated. This study was performed on male Wistar rats. The rats were divided into three groups, namely the control, sham and cholestatic groups. After two weeks, the rats were killed under anesthesia and their brains were dissected with no delay. The specimens were processed routinely and were sectioned into slices of 6-micron thickness. The sections were stained by Hematoxiline-Eosin (H\&E) method. Subsequently, they were studied using optical microscope. Necrotic cells, the diminution of cell density and wrinkled chromatic nuclei were observed in hippocampus section. In addition, the thickness of hippocampus was mostly decreased. However, in the sham and control groups no changes were observed. Since endotoxin causes tissue trauma, the increase of endotoxin may result in tissue changes in the brain.
\end{abstract}

Keywords. bile, endotoxin, hepatic encephalopathy, necrosis 
(Moezi et al., 2006; Dingon et al., 2011; انجامد مقدمه Ghaffuri et al., 2004; Kiani et al., 2009; Hasanein et (al., 2007 همجنين، بر اثر كلستاز ميزان اوبيوئيدها نيز افزايش مى يابد. دربارهء افزايش اوييوئيدها هنوز دليل قطعى وجود ندارد، اما امكان دارد كه بر اثر درد ناشىاز كلستاز توليد اين تركيبات در مغز افزايش يابد (Hasanein et al., 2007). ادامه كلستاز مى تواندآسيبهاى بافتى نظير فيبروز كبدى، سيروز كبدى، هياتيك آن آنسفالوياتى و ادم مغزى را ايجاد كند (Cauli et al., 2009; (Wright et al., 2007 در خون افزايش مى يابد. اندوتوكسينها تركيباتى سمى با قابليت عبور از سد خونى مغزى هستند. درواقع، اين تركيبات بهوسيلة باكترىهاى كرم منفى روده توليد و بر اثر صفرا به تركيباتى بى ضرر مبدل مىشوند، ولى بر اثر كلستاز و عدم ورود صفرا به روده ميزان اين مواد در خون افزايش مىيابد (Moezi et al., 2006).

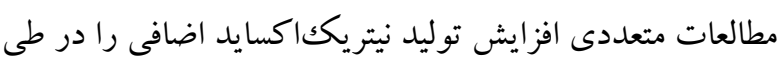
كلستاز و فيبروز كبدى نشان مىدهند. براساس تحقيقات ييشين، افزايش بيشازحد اندوتو كسينها در جريان خون، يساز كلستاز، و عمل كرد آنها ازطريق سيتوكينهاباعث القاى توليد بيشازحد نيتريك اكسايد در مغز مىشود (Mani et al., 2000). حافظه روندى است كه طىآن اطلاعات ذخيره و بازيابى مىشوند (Kande et al., 2000). حافظه در سينايسها ذخيره مىشود (Tehranipour et al., 2011) و سينايسهاى آن عاملى مؤثر در افزايش و كاهش حافظه است.هيبو كامب نقش مهمى در ايجاد حافظه بهعهده دارد. اين ناحيه از مغز توسط شريان كروئيد قدامى، كه شاخهاى از كاروتيد داخلى است، خونرسانى مىشود. اين شريان، بهدليل بلند و نازككبودن، مستعد ترومبوزيس است. بنابراين، هييوكامٍ جزء اولين مناطقى از مغز است كه در بيمارىهاى مختلف نظير آلزايمر، هانتيكتون، صرع، سكته مغزى، ايسكمى و بهويزه تروماى مغزى

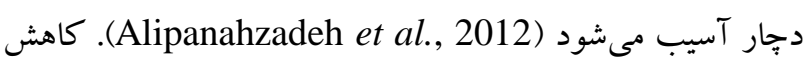
حجم هييو كامٍ مى تواند اختلالاتى را در حافظه و ياد گيرى ايجاد كند. تغيير در تعداد نورونهاى هييو كامٍ مى تواند به تغيير حجم هيبو كامٍ منجر شود، همجنانكه بهطور مشابهى در بيمارى آلزايمر كاهش تعداد نورونها مشاهده مىشود و عمل كرد كاهش مى يابد. هيبو كامٍ بخشى از سيستم ليمبيك است و بهعلت شباهتى

كلستاز بهلحاظ فيزيولوزيكك به توقف يا كاهش جريان صفرا از كاناليكولهاى صفر اوى به دئودنوم روده كفته مىشود و مى تو اند به دو صورت داخل كبدى و خارج كبدى يا انسدادى ايجاد شود (Moezi et al., 2004; Moezi et al., 2006) كبدى عملكرد هياتوسيتهاى كبد با مشكل روبهرو و توليد صفرا قطع مىشود ولى در نوع خارج كبدى يا كلستاز انسدادى، مجرا بهدلايل مختلف، ازجمله كوله ليتازيس، كارسينوماى سر يانكراس، تومورهاى مجراى صفراوى، و كيسٔ صفر ا،بسته مىشود و صفراى توليدشده بهجاى ورود به روده، وارد جريان خون مىشود و عوارضى را ايجاد مى كند كه سبب تشخيص بيمارى مىشود. دورهٔ اين بيمارى سه هفته است كه بعداز اين دوره، بيمارى مزمن مى شود و تبديل به سيروز كبدى مىشود ( Podolsky et al., 1998; Nahavandi et al., 2001; Dehpour et al., 2002; (Narimani et al., 2001 ناكارآمدى در دفع صفرا به تخريب پيارانشيم كبدى، يروليفراسيون سلولهاى إيتليال، فعالشدن سلولهاى ستارهاىشكل كبدى، توليد سيتو كينها و درنهايت فيبروز بيشروندهُ بافت كبد مى انجامد. سلولهاى ستارهاىشكل كبدى سلولهايى هستند كه بهطور معمول در فضاى بين سلولهاى پيارانشيم كبدى و سلولهاى اندوتليال سينوسهاى كبدى قرار دارند و نقش آنها ذخيره رتينوئيد و جربى است. اين سلولها در وضعيت ياتوفيزيولوزيك نظير فيبروز كبد، رتينوئيد خود را از دست مىدهند و بهشكل فيبروبلاستها يا ميوفيبروبلاستها مبدل مىشوند. همجنين در اين موقعيت ماتريكس خارجسلولى را توليد مى كنند كه در باز گشت Hong et al., 2007; Chang et ) عمل كرد آنها كمكك مى كند .(al., 2005; Senoo et al., 2004 از عوارض شايع كلستاز خارج كبدى مىتوانيم به افزايش غلظت نمككهاى صفراوى، رنخدانههاى صفراوى، كلسترول، اسيدهاى جرب، فسفاتيديلكولين، آلكالينفسفاتاز و بروستا گلندينها در خون اشاره كنيم، علت افزايش اين تركيبات وجود آنها در صفرا، و ورود صفرا به خون است. افزايش بيشازحد اسيدهاى صفراوى در جريان خون و تجمع آنها در مغز، به افزايش اسيديتهُ (كاهش (PH مغز و تحريك هسته سويراليتيك نو كلئوس (PON) هيبوتالاموس و توليد بيشازحد آرزينين -وازوبرسين در مغز مى - 
نشانه هاى كلستاز (زردى، ادرار تيره، اسهال خرب) مشاهده شد كه

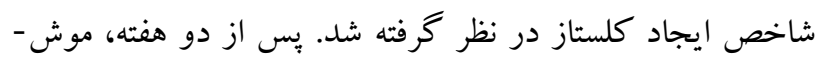

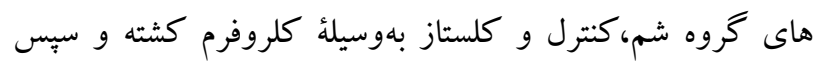
تشريح شدند.

\section{روش مطالعأ بافتى}

مغزهاى موشها بهمنظور تثبيت به فرمالين·ادرصد منتقل و

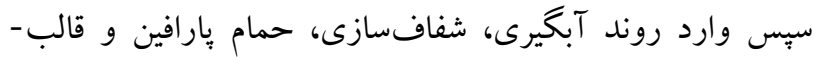

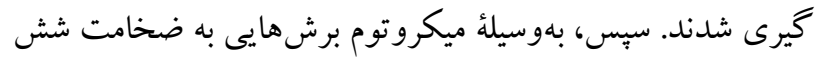
ميكرون از آنها تهيه شد. بساز رنغكآميزى با هماتوكسيلين-

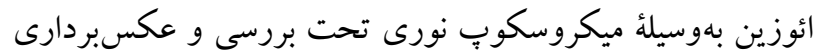

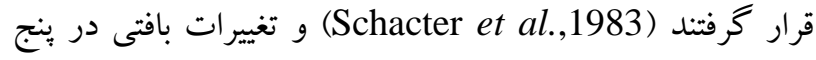
لام ودر بنج ميدان ديد بهصورت تصادفى ارزيابى شدند. بهمنظور

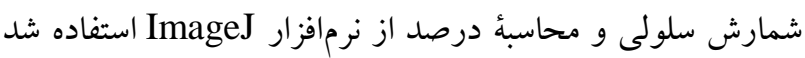
(Lavazza et al., 2010) ضخامت نواحى مختلف، با قراردادن

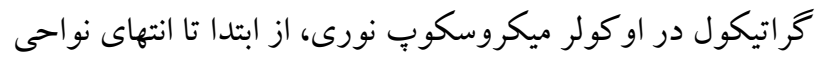

$$
\text { روش و وابيو كامب بر حسب ميكرومتر اندازهگيرى شد. }
$$

محاسبات باستفاده از روش تحليل واريانس يككطرفه براى اطراي

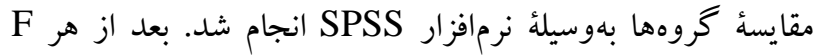

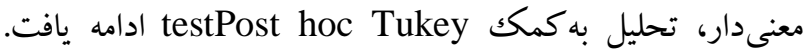
ازلحاظ آمارى p كمتر از هـ/ معنىدار فرض شد. شمارش سلولى با نرمافزار Image أنجام شد. أند.

\section{نتايج}

بررسى هاى صورت كرفته حاكى از مركَ سلولى بههمر اه كاهش

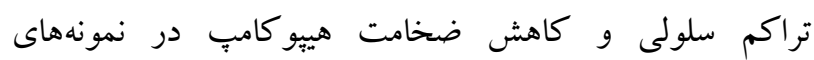

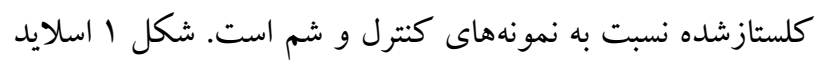

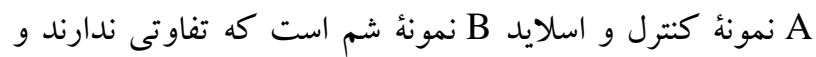
مقايسٔ آنها با اسلايد C كه شكل نمونه كلستاز است تفاوتهاى بافتى را نشان مىدهد. باتوجه به بررسىهاى مورفولوزى مشخص شه شد كه هييو كامٍ در

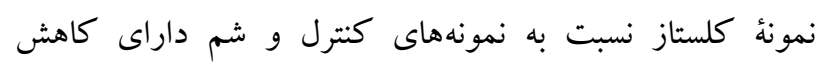
ضخامت بوده و بررسىهاى كمى نيز مؤيد اين موضوع است.

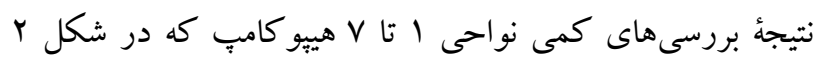
بإيكان مشخص شدهاند در جدول شماره ا مشاهده مى لثود. البته
كه به اسب دريايى دارد به اين نام معروف شده و داراى بخشهاى مختلفى شامل , CA است (Tehranipour et al., 2011). تحقيقات بيشين نشان دادند كه كلستاز به كاهش حافظه و افزايش اندوتو كسينهامنجر مىشود و هر دو اين عوامل مىتوانند باعث تخريب بافت

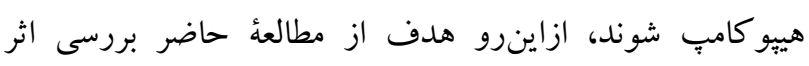

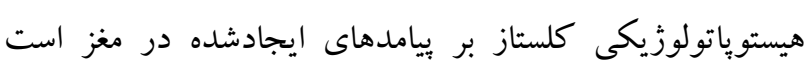

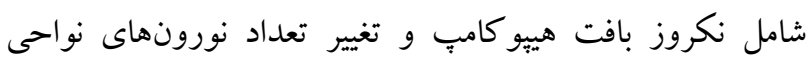

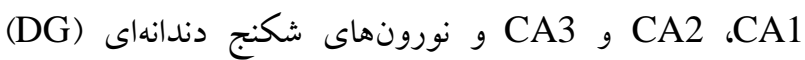

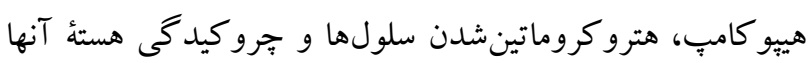

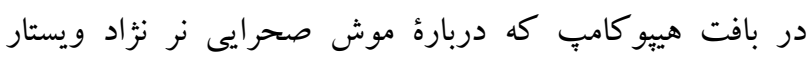

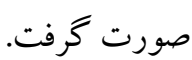

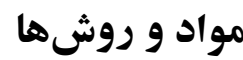

در اين مطالعهُ تجربى از موشهاى نر نزاد ويستار در محدودهٔ

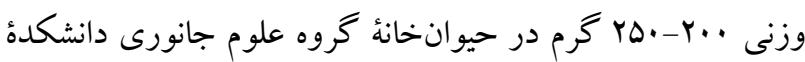

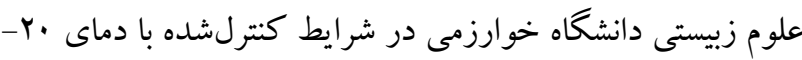

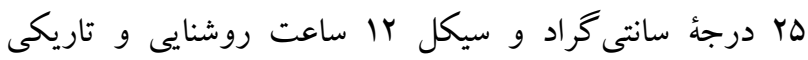
استفاده شد. كلئ موشها دسترسى آزادانه به آب آشاميدنى و

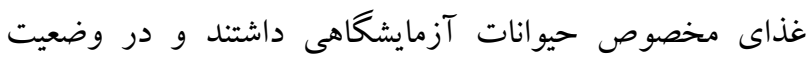
يكسان نگهدارى مىشدند. در اين تحقيق موشها به سه گروه هشت تاييكنترل، شم و كلستاز تقسيم شدند.

\section{جر احى شم و كلستاز}

در جراحى كلستاز (بستن مجراى صفراوى)، ابتدا موشها با لإن

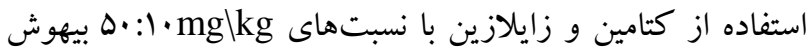

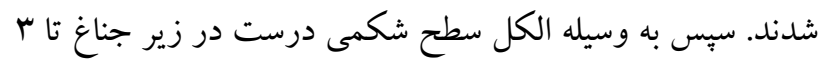
سانتىمترى بايينتر از استخوان جناغ ضدعفونى و به وسيلة تيغ موهاى اين ناحيه تراشيده شد و يوست و عضله در دو مرحله جدا

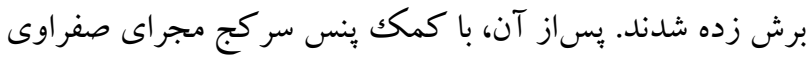

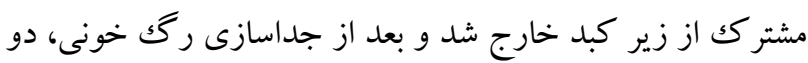

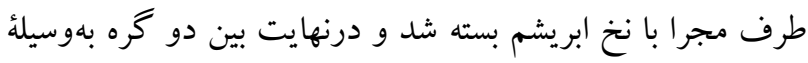

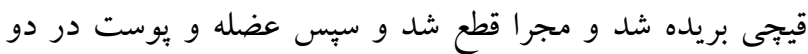

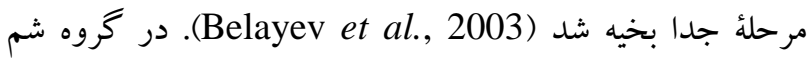
تمام مراحل ذكرشده براى عمل كلستاز انجام شد، ولى مجرا بسته نشد. دو روز بعد از مسدودكردن مجراى صفراوى، در حيوانات 

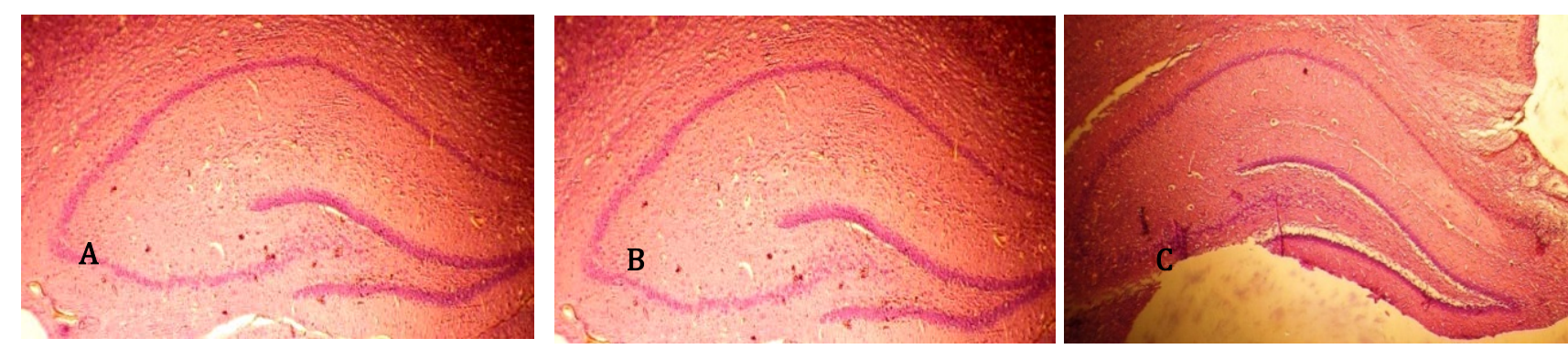

شكل 1 - مقاطع بافت هييو كامٍ. اسلايد A: نمونهُ كنترل، اسلايد، B: نمونهُ شم و اسلايد C: نمونهُ كلستاز است كه دجار نكروز بافتى شده است (بزر گنمايى × •F، رنغك آميزى هماتو كسيلين - ائوزين).

Fig. 1. Hippocampal tissue sections, A: control, B: sham, C: cholestasis brain tissue necrosis were increased in cholestatic sample, (40X- H\&E).

بررسىهاى بافتى ناحية CA3 هييو كامٍ حاكى از وقوع نكروز،

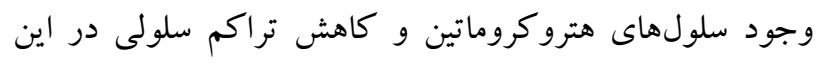
ناحيه در نمونههاى كلستازى است. درصورتى كه جنين تغييرات

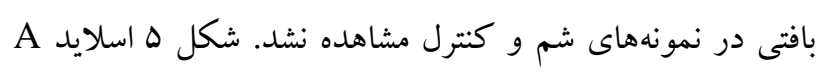
نمونه كنترل و اسلايد B نمونهُ شم است، كه داراى تفاوت

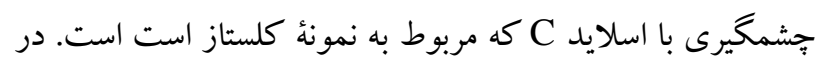
نمونه كلستاز سر بيكان سلولهاى هترو كروماتين را نشان مىدهد.

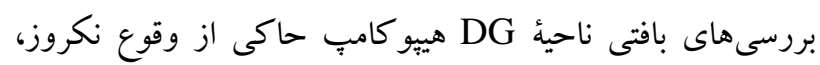
كاهش تراكم سلولى و وجود سلولهاى هتروكروماتين در اين باتسي

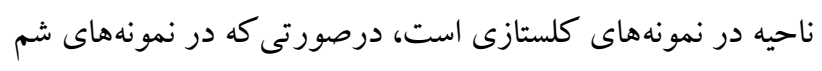

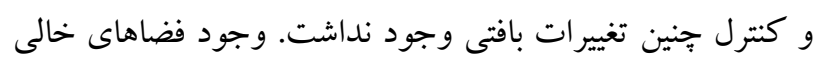

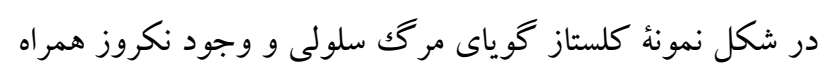

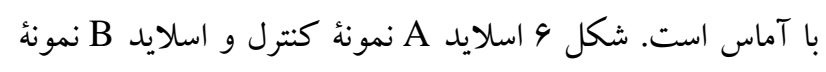

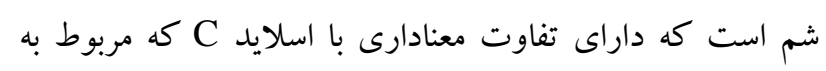

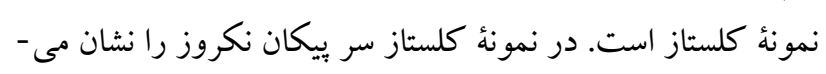

دهد.

بررسى هاى كمى نواحى مختلف هييو كامٍ نشان داد كه تعداد سلولهاى سالم در اين نواحى در نمونهاى كلستاز نسبت به نمونه-

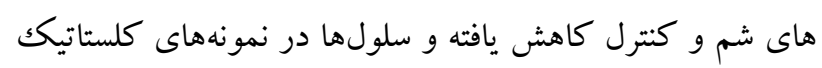
دجار نكروز و هتروكروماتين شدهاند درصورتى كه خهنين تغييرات بافتى در نمونههاى كنترل و شم وجود ندارد. نتايج حاصل ازاين

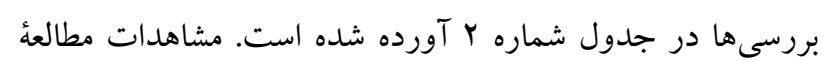

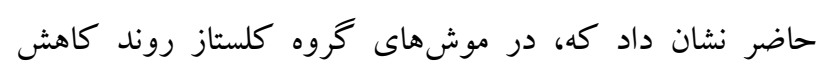

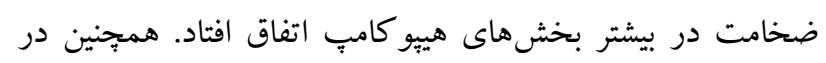

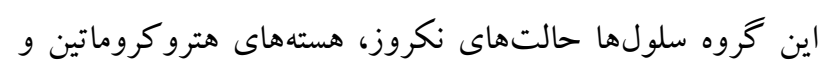

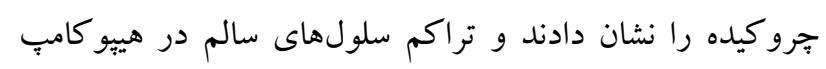

كاهش ضخامت در نواحى بَ و ا اتفاق نيفتاده و دادههاى آن ازنظر آمارى بىمعنى بودند.

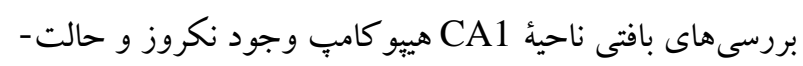
هاى هتروكروماتينىشده رادر نمونههاى كلستازى در مقايسه با بإسية همين ناحيه در نمونههاى كنترل و شم نشان داد. در اين ناحيه از

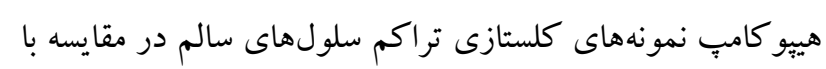

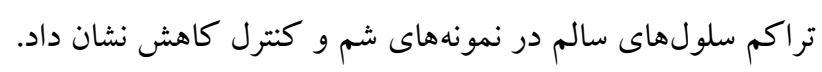

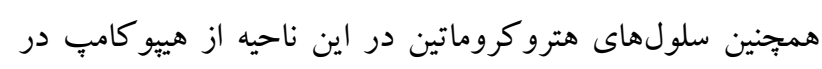

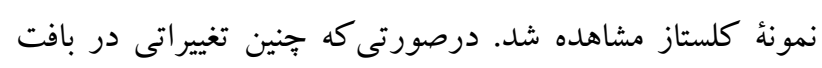

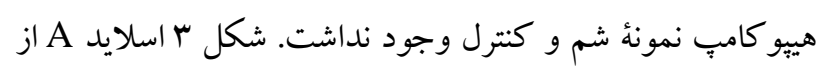

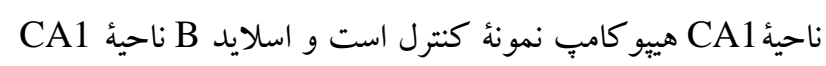

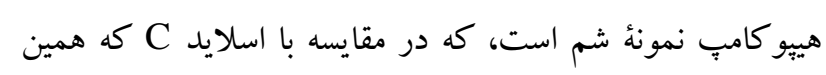
ناحيه در نمونه كلستاز است ضخامت بيشترى دارند و سلولهاى آنها سالم و بدون نكروز و بهصورت يو كروماتينى است. بيكان سفيد نشان دهنده سلولهاى هتروكروماتين در ناحية CA1 است است بررسىهاى كيفى ناحئ CA2 حاكى از وقوع نكروز در بافتهاى

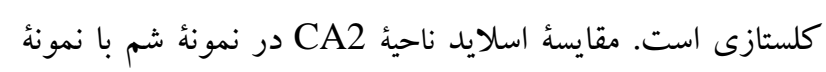
كنترل تفاوتى را نشان نمىدهد، درصورتى كه مقايسة آنها با اسلايد

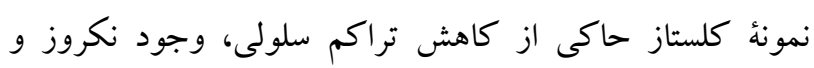

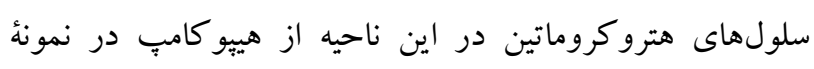

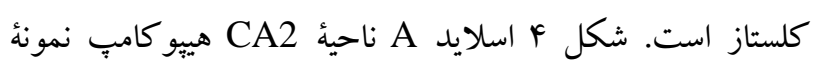
كنترل و اسلايد B ناحية CA2 هييو كامٍ نمونه شم است، كه

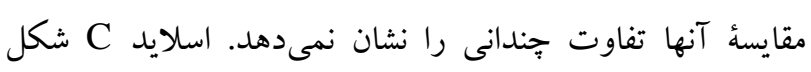

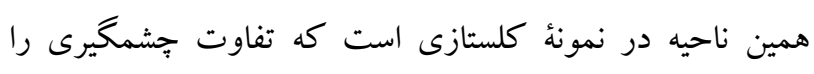

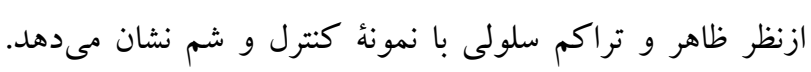
ييكان گوياى سلولهاى نكروز و هتروكروماتين است. 


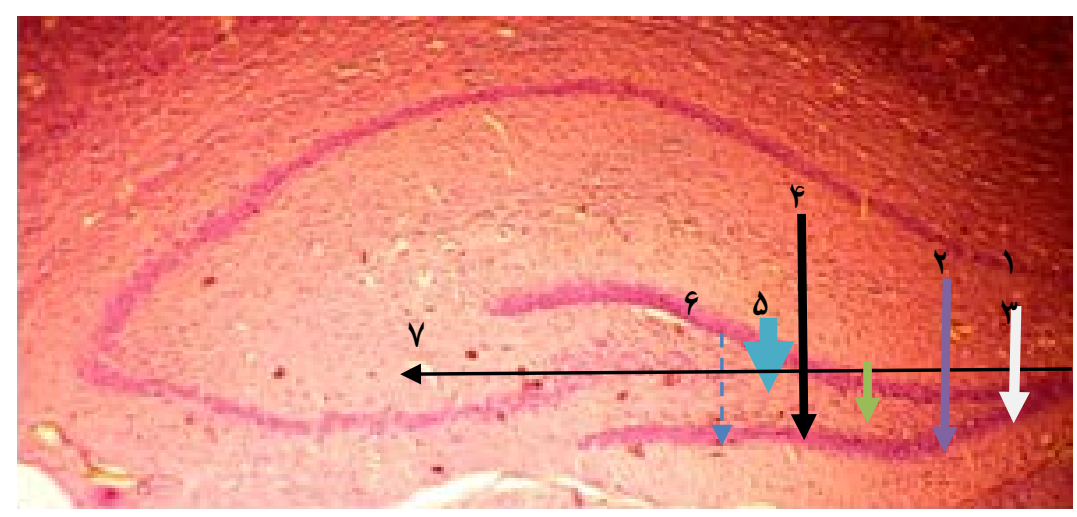

شكل r- نواحى هيبو كامب (بزر گنمايى × · F).

Fig. 2. Hippocampus regions (40X).

$$
\text { جدول ا- ضخامت نواحى هييو كامب در گروههاى كنترل، شم و كلستاز، Mean I SE، }
$$

Table 1. Thickness of hippocampal regions in control, sham and cholestasis groups. Mean \pm SE, $p<0.05$.

\begin{tabular}{|c|c|c|c|c|c|c|c|}
\hline $\begin{array}{c}\text { ضخامت ناحيه } \\
(\mu \mathrm{m})\end{array}$ & 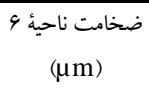 & $\begin{array}{c}\text { ضخامت ناحئ هائ } \\
(\mu \mathrm{m})\end{array}$ & 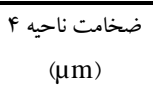 & ضخامت ناحيه ب & $\begin{array}{c}\text { ضخامت ناحيه } \\
\text { Y }\end{array}$ & ضخامت ناحية 1 (رm) & كروه \\
\hline$r Y Q \Delta / r I \pm F F / V Y$ & $r \cdot r / 9 \pm \cdot / / r$ & $|9 r / f \pm \Lambda / 1|$ & $90 \cdot / 11 \pm 0 \cdot / 1 r$ & $\mid \wedge 9 / 1 \cdot \pm 0 \cdot / \cdot 9$ & $\Delta r q / \backslash \Lambda \pm r / \cdot 1$ & $r q q / f \pm \cdot v / r$ & كنترل \\
\hline$r r \cdot Y / Y G \pm \cdot Q / \Delta Y$ & $r \cdot r / \Delta \pm r / r r$ & $19 \Delta / f \pm \Lambda / r \Lambda$ & $9 \Delta F / Q \pm \cdot / \mu r$ & $|\wedge Q /| \cdot \pm V \cdot / r \mid$ & $\Delta Y N / I V \pm q / F$ & $r q \Lambda / f \pm \cdot / r V$ & شم \\
\hline$r \cdot V F / Y F \pm \cdot / r \Lambda$ & $r V q / r \pm q / V$. & $|V| / Y \pm q / 9 Y$ & $G \times r / \Delta \pm \Delta / r 1$ & $19 V / \Delta \pm 1 / r \mu$ & $F q \cdot / 1 Y \pm 1 / r r$ & $r|V / V \pm \Lambda / F|$ & كلستاز \\
\hline$\because \square$ & $* \square$ & $\because \square$ & & & $* \square$ & $* \square$ & \\
\hline
\end{tabular}

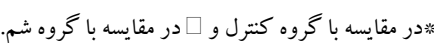

*in compare with control group, $\square$ in compare with sham group
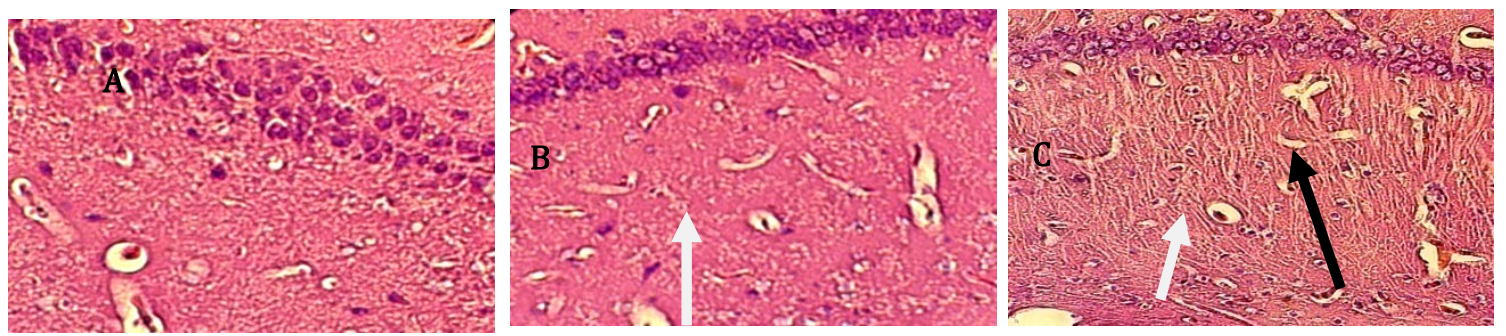

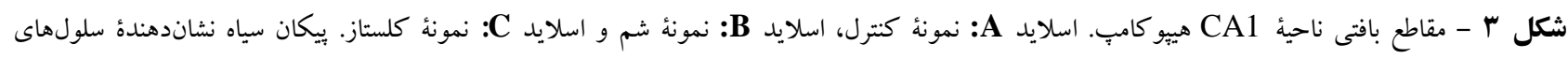

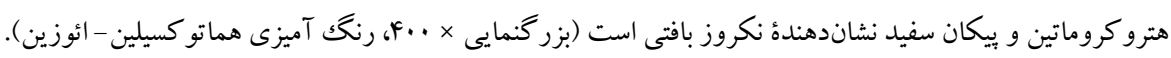

Fig. 3. Hippocampal CA1 region tissue slides, A: control, B: sham, C: cholestasis. Heterochromatin cells (black arrow), tissue necrosis (white arrow), (400X- H\&E). 

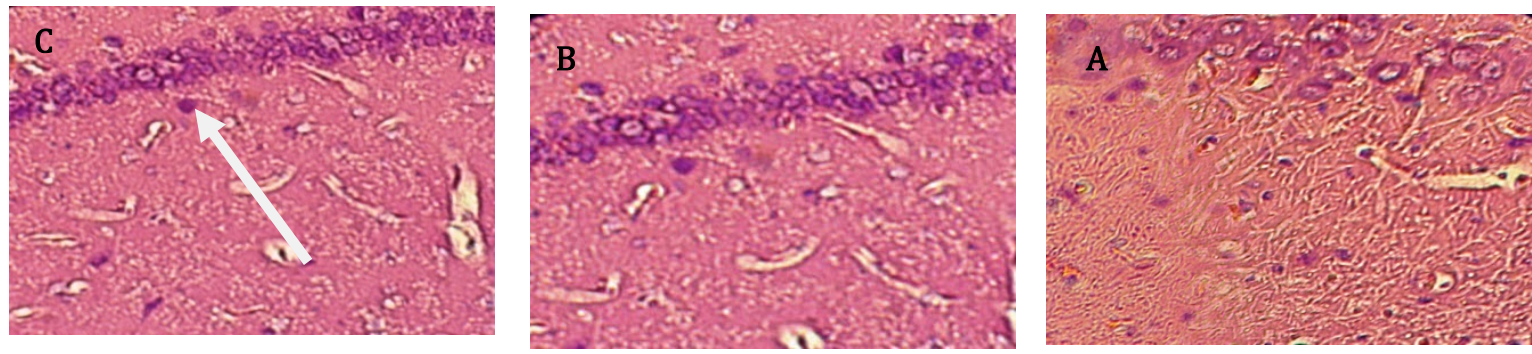

شكل ع- مقاطع بافتى ناحئ CA2 هييو كامٍ اسلايد. A: نمونه كنترل، اسلايد B: نمونهُ شم و اسلايد C: Cمونه كلستاز. بيكان سياه نشان دهندة سلولهاى

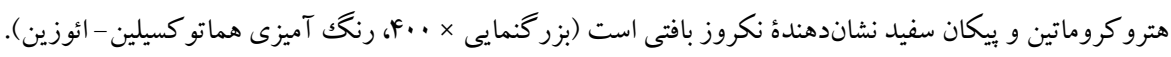

Fig. 4. Hippocampal CA2 region tissue slides, A: control, B: sham, C: cholestasis. Heterochromatin cells (black arrow), tissue necrosis (white arrow), (400X- H\&E).
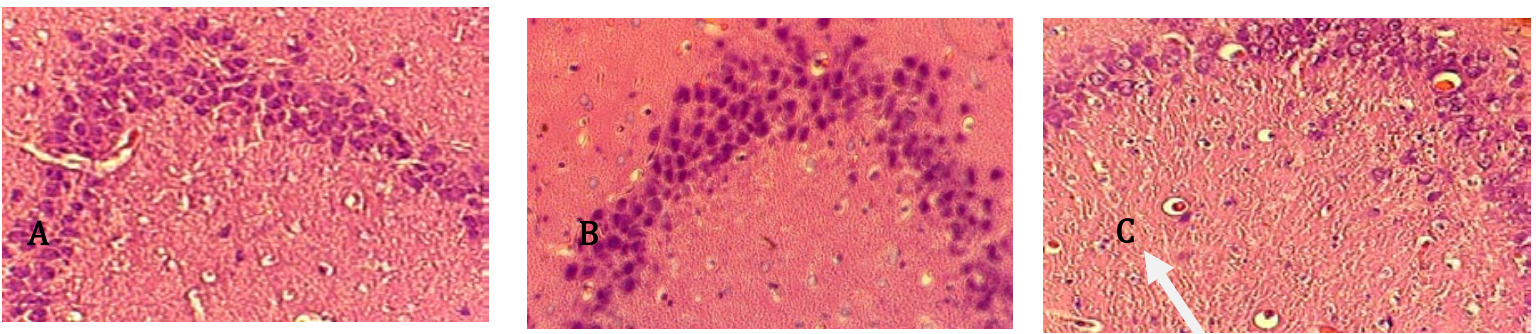

شكل 0- مقاطع بافتى ناحية CA3 هييو كامب. اسلايد A: نمونهُ كنترل، اسلايد B: نمونهُ شم و اسلايد C: نمونهُ كلستاز. بيكان سياه نشان دهنده سلولهاى

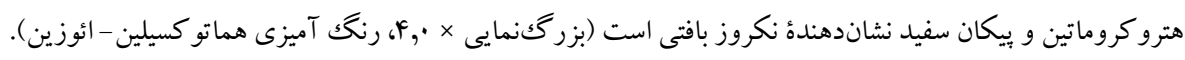

Fig. 5. Hippocampal CA3 region tissue slides, A: control, B: sham, C: cholestasis. Heterochromatin cells (Black arrow), tissue necrosis (white arrow), (400X-H\&E).
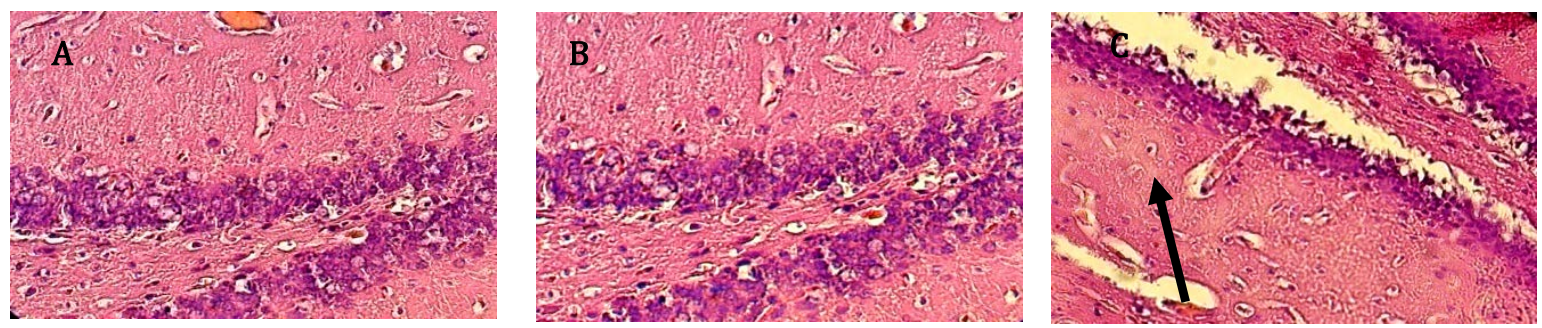

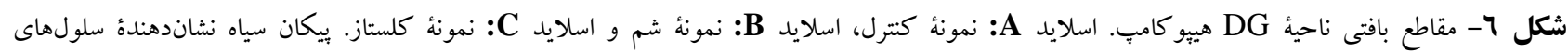

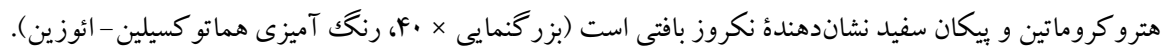

Fig. 6. Hippocampal DG region tissue slides, A: control, B: sham, C: cholestasis. Heterochromatin cells (black arrow), tissue necrosis (white arrow), (400X-H\&E).

حالتهاى هتروكروماتينى در نواحى ذكر شده هيبو كامبٍ منجر

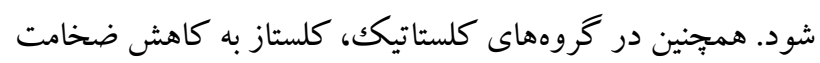
هيبو كامٍ در نواحى مختلف منجر شد، علاوه بر اين در گروههاى كلستاتيك دزنره شدن سلولهاى عصبى در ناحية DG هيبو كامٍ مشاهده شد. هييو كامٍ جزء اولين مناطقى از مغز است كه در بيمارىهاى مختلف نظير آلزايمر، هانتيكتون، صرع، سكته مغزى، ايسكمى و بويزه تروماى مغزى دجار آسيب مىشود. تحقيقات

$$
\begin{aligned}
& \text { آنها كاهش يافته بود. در صورتى كه در گروههاى شم و كنترل } \\
& \text { جنين تغييرات بافتى رخ نداده بود. }
\end{aligned}
$$

\section{بحث و نتيجه Fيرى}

نتايج مطالعهُ حاضر نشان داد كه كلستاز مىتواند به تخريب نورونهاى هيبو كامٍ در نواحى CA1,CA2,CA3، تخريب نورونهاى لايه گر انولار DentateGyrus) DG)، ايجاد نكروز و 


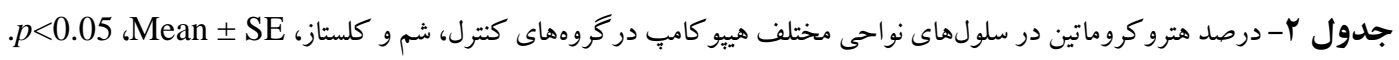

Table 2. Heterochromatin percentage in the cells of hippocampal regions in control, sham and cholestatic groups. Mean $\pm \mathrm{SE}, p<0.05$.

\begin{tabular}{|c|c|c|c|c|}
\hline ناحئi & ناحية CA3 & ناحية CA2 & ناحيidCA1 & كروه \\
\hline r & $\cdot / \cdot \pm \cdot /$ & $\cdot / \cdot \pm \cdot /$ & $\cdot / \cdot \pm \cdot /$ & كنترل \\
\hline$\cdot / \cdot \pm q \cdot / k q$ & $\cdot / \cdot \pm \cdot /$ & $\cdot / \cdot \pm \cdot /$ & $\cdot / \cdot \pm 1 \cdot / 1$. & شم \\
\hline$r I / r \pm V \cdot / V Y * *^{\prime} \square$ & $r / r \cdot \pm r / \cdot \Lambda * \square$ & 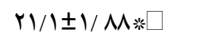 & $r r / r \pm 9 / \cdot 9 * \square$ & كلستاز \\
\hline
\end{tabular}

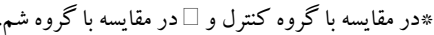

*in compare with control group, $\square$ in compare with sham group.

صورت مزمن مى تواند نوروزنز ناحية DG هيبو كامب را متوقف

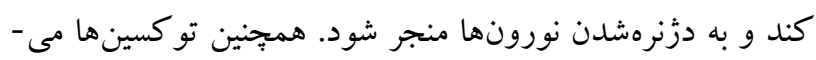

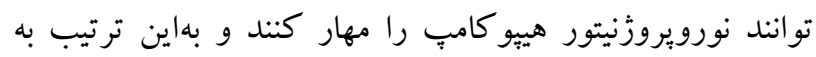
Harry et al., 1992; ) تغييرات بافتى در هييو كامٍ منجر شوني .(Qin et al., 2008 و همكاران (2008) اثبات نمودند كه افزايش تو كسينها مى تواند باعث توليد TNFaدر كبد شود ويساز توليد توسط سلول هاى كويفر وارد خون شده و ازطريق رسيتورهاى خود از سد بد بد خونى - مغزى عبور نموده و وارد مغز شود. همجنين طبق بررسى

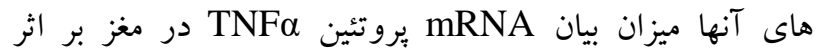

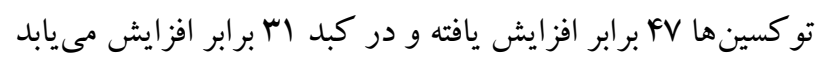

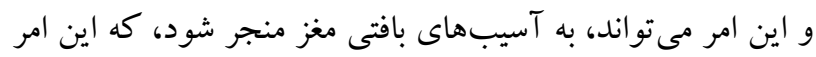
با نتايج مطالعة حاضر مطابقت دارد. Iwai و همكاران (2001) نشان دادند، كه سلولهاى كويفر كبدى اين توانايى را دارند كه،

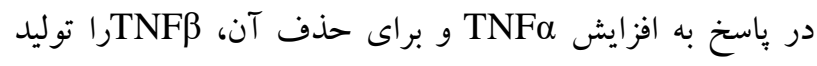
كنند. همجِنين Prins و همكاران (2005) اثبات كردند كه سلولهاى كويفر نقش كليدى در ميزان TNFa خون و ساير بافتها را،

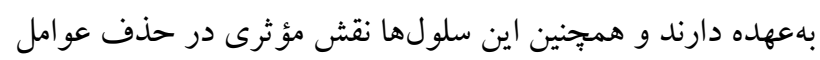

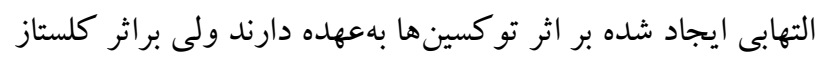

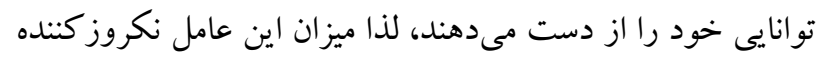

$$
\text { در خون افز ايش مى يابد. }
$$

در اين مطالعه تغييرات مشاهده شدهُ جهارده روز بس بـاند كلستاز

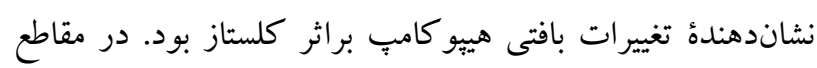

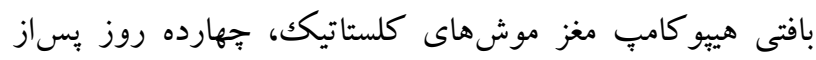

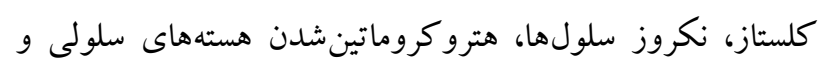

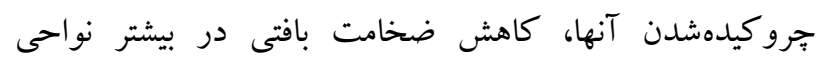

نشان مىدهند كه كلستاز مىتواند التهاب بافت مغز و كاهش حافظه را ايجاد كند و تحقيقات ديخر بر ساختار بافتى هييو كامب دهن

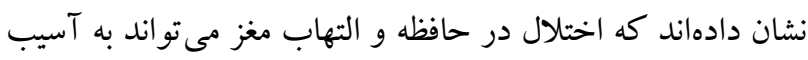
بافتى هييو كامٍ منجر شوند كه اين امر با نتايج اين مطالعه مطابقت

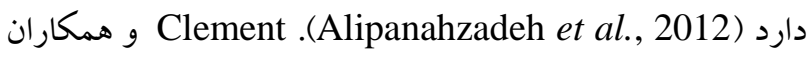
(1992) نشان دادند، كه در گروههاى كلستاتيك و بر اثر كلستاز سلولهاى كويفر كبدى توانايى ياكسازىشان كاهش يافته و ميزان

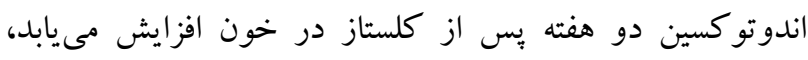

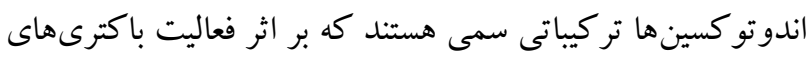

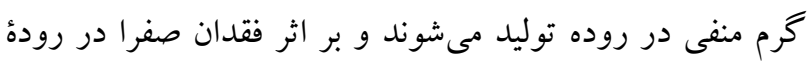

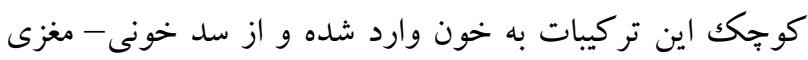
عبور نموده و وارد مغز مى شوند. Harry و همكاران (1999) بيان

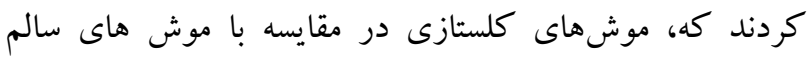
حساسيت بيشترى نسبت به اندوتوكسينها دارند و سلولهاى كبدى در موشهاى كلستازى دجار مرگك سلولى مىشوند. همجِين نشان دادند كه در موشهاى كلستازى ميزان TNFa، افزايش جشمخيرى را نشان مىدهد، كه اين عامل نكروز كنندة تومور مىتواند در مر گك سلولهاى كبد مؤثر باشد. Wright و همكاران (2007) نشان دادند، كه اندوتو كسينها در موشهاى كلستازى مىتواند به ايجاد كما و ادم منجر شوند، آنها

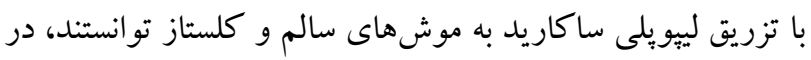
موشهاى كلستازى حالتهاى قبل از كما و ادم سيتوتو كسيكك را

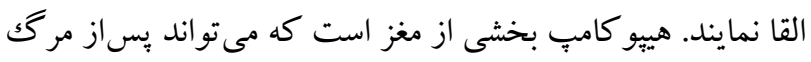
نورونهايش، مجدد تكثير نورونها را داشته باشد، اما تحقيقات

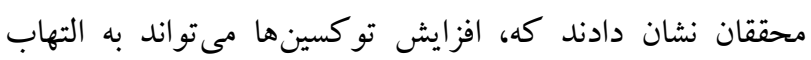
نورونها و كاهش نوروزنز منجر شود. افزايش توكسينها بهـ 


\section{REFERENCES}

Alipanahzade, H., Soleimani, M., Soleimani, A., Mehdizadeh, M. and Katebi, M. 2012. Effect of transforming growth factor alpha of dentyte jyrus neurons and pyramidal cells of CA1 subfiled of hippocampus following ischemia-reperfusion in rats. - J. Gorgan University of Med. Sci. 14: 21-27.

Belayev, A., Saul, I., Liu, Y. and Zhao, W. 2003. Enriched environment delays the onset of hippocampal damage after global cerebral ischemia in rats. - Brain. Res. 964: 121-127.

Cauli, O., Rodrigo, R., Liansola, M., Montoliu, C., Monfort, P. and Piedrafita, B. 2009. Glutamatergic and gabaergic neurotransmission and neuronal circuits in hepatic encephalopathy. - Metab. Brain. Dis. 24: 69-80.

Chang, M.L., Yeh, C.T., Chang, P.Y. and Chen, J.C. 2005. Comparison of murine cirrhosis models induced by Hepatotoxin administration and common bile duct ligation. - World J. Gastroenterol. 11: 4167-4172.

Dehpour, R., Seyyedi, A., Rastegar, H., Namirani, K., Moezi, L. and Sadeghipour, H. 2002. The non-adrenergic non-cholinergic relaxation of anococcygeus muscles of bile duct-ligated Rats. - Eur. J. Pharmacol. 445: 31-36.

Ghaffuri, K., Tourr Savadkouhi, S., Honar, H., Riazi, K., Shafaroodi, H., Moezi, L., Ebrahimkhani, M.R., Radjabzadeh Tahmasebi, M.S. and Dehpour, A.R. 2004. Obstructive cholestasis alters intestinali transit in mice: role of opioid system. - Life Sci. 76: 397-406.

Gharoony, F., Oryan, Sh., Nabiuni, M., Eslimi Esfahani, D., Hosseinynia, T., Karimian Peiro, M. and Parsa, S. 2015. The histopathological effects of cholestasis on hypothalamic paraventricular and supraoptic nucleus on male Wistar rats -.Nova Biologica Rep. 1: 77-85.

Harry, D., Anand, R., Holt, S., Davies, S., Merley, R., Frnando, B., Goodier, D. and Moore, K. 1999. Increased sensitivity to endotoxemia in the bile duct ligated cirrhotic rat. - Hepato. 30: 1198-1205.

Hasanein, P., Parviz, M., Keshavarz, M., Javanmardi, K., Allahtavakoli, M. and Ghaseminejad, M. 2007. Modulation of cholestasis-induced antinociception in rats by two NMDA receptor antagonists: MK-810 and magnesium sulfate. - Eur. J. Pharma. 554: 123-127.

Hong, J.Y., Sato, E.F., Hiramoto, K., Nishicawa, M. and Inoue, M. 2007. Mechanism of liver injury during Obstructive jaundice: role of nitric oxide splenic cytokines, and intestinal flora. - J. Clin. Biochem. Nutr. 40: 184193.

Iwai, M., Cui, T.X., Kitamura, H., Saito, M. and Shimazu, T. 2001. Increased secretion of tumour necrosis factor and interleukin 6 from isolated, perfused liver of rats after partial hepatectomy. - Cytokine 13: 60-64.

Kande, E.R., Schwartz, J.H. and Jessel, T.M. 2000. Principlels of Neural Science. $-1^{\text {st }}$.New York: Mc. GrawHill. pp: 10-35.

Kiani, S., Valizadeh, B., Hormazdi, B., Samadi, H., Njafi, T., Samini, M. and Dehpour, A.R. 2009. Ateration in male reproductive system in experimental cholestsis roles for opioids and nitric oxide overproduction. - Eur. J. Pharmaco. 615: 246-251.

$$
\begin{aligned}
& \text { هيبو كامب و كاهش تراكم سلولهاى سالم مشاهده شد كه ادامه } \\
& \text { اين امر مىتواند با تخريب حافظه همراه باشد كه با مطالعات قبلى } \\
& \text { نويسند كان اين مقاله همخوانى دارد (Gharoony et al., 2015). } \\
& \text { اين احتمال وجود دارد كه افزايش اندوتو كسينها و آثار منفى آن- } \\
& \text { ها بر ساختار بافتى هيبو كامٍ به ايجاد جنين تغيير اتى منجر شود كه } \\
& \text { البته، اظهار نظر قطعى در بارهُ آن نياز به مطالعهُ بيشترى دارد. }
\end{aligned}
$$

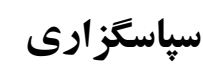

نكارند گان از خانمها طليعهالسادات حسينىنيا و فاطمه قارونى

$$
\text { بهخاطر همكارىهاى بى دريغشان، تشكر و قدردانى مىنمايند. }
$$


Lavazza, C., Carlo-Stella, C., Giacomini, A., Cleris, L. and Righi, M. 2010. CD34 cells engineered to express membrane-bound tumor necrosis factor related apoptosis-inducing ligand target both tumor cells and tumor vasculature. - J. Gastroente. 139: 675-684.

Mani, A., Nahavandi, A. and Dehpour A.R. 2000. Role of nitric oxide in hypodipsia in rats with obstructive cholestasis. - J. Pharm. Pharmaco. 53: 227-234.

Moezi, L., Rezayat, M., Samini, M., Shafaroodi, H., Ejtemie, S.H., Ebrahim Khani, M.R. and Dehpour, A.R. 2004. Potentiation of anandamide effects in mesentric beds isolated from bile duct-ligated rats: role of nitric oxide optic tectom. - Eur. J. Pharmaco. 489: 53-59.

Moezi, L., Shafaroodi, H., Sarcar, S., Emami-Razavi, S.H., Sanatkar, M., Mirazi, N. and Dehpour, A.R. 2006. Involvement of nitrergic and opioidergic systems in the hypothermia by cholestasis in rats. - J. Pathophys. 13: 227-232.

Nahavandi, A., Dehpour, A.R., Mani, A., Homayounfar, H., Abdoli, A. and Abdolhoseini, M.R. 2001.The role of nitric oxide in bradycardia of rats with obstructive cholestasis. - Euro. J. Pharmaco. 411: 135-141.

Narimani, K., Samini, M., Ejtemaei mehr, S., Gaskari, S.A. and Rastegar, H. 2001. Mesentric vascular bed responsiveness in bile duct-ligated rat's: roles of opioid and nitric oxide systems. - J. Pharmaco. 423: 185-193.

Podolsky, D.K. and Dienstay, J. 1998. Liver and Billiary Tract Diseases In: Harrison's Principles of Internal Medicine. $-14^{\text {th }}$ Editions Eugene Braunwald, AB Isselbacher, J Kurt, Mc. Grawhill. 1437-1516 pp.

Prins, H.A., Meijer, C., Boelens, P.G., Nijveldt, R.J., Siroen, M.P., Masson, S., Daveau, M., Scotte, M., Diks, J. and van Leeuwen, P.A. 2005. The role of Kupffer cells after major liver surgery. - J. Parenter. Enteral. Nutr. 29: 48-55.

Qin, L., He, J., Hanes, R., Pluzarev, O., Hong, J.S. and Crews, F.T. 2008. Increased systemic and brain cytokine production and neuroinflammation by endotoxin following ethanol treatment. - J. Neuroinflamm. 128: 200-204.

Schacter, B.A., Joseph, E. and Firneisz G. 1983. Effect of cholestasis produced by bile duct ligation on hepatic heme and hemoprotein metabolism in rats. - Gastroentero. 2: 227-235.

Tehranipour, M. and Sabzalizade, M. 2011. Effect of cannabis sativa alcoholic extract on hippocampus neuronal on density in Rats. - J. Gorgan University of Med. Sci. 13: 12-17.

Wright, G., Davies, N.A., Shawcross, D.L., Hodges, S.J., Zwingmann, C., Brooks, H.F., Mani, A.R., Harry, D., Stadlbauer, V., Zou, Z., Wiliams, R., Davies, C., Moore, K.P. and Jalan, R. 2007. Endotoxemia produces coma and brain swelling in bile duct-ligated rats. - Hepato. 46: 1517-1526.

$* * * * *$

How to cite this article:

Eslimi Esfahani, D., Oryan, Sh., Nabiuni, M. and Karimian Peiro, M. 2017. The role of cholestasis in brain hippocampus trauma in male Wistar rat. - Nova Biologica Rep. 4: 128-136.

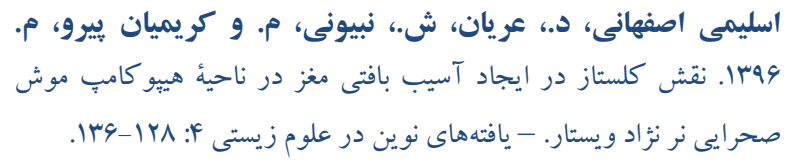


